\title{
A young woman presented with massive pulmonary embolism with inferior vena cava thrombus as a complication of nephrotic syndrome: a case report
}

\author{
Mohamed Osman Omar Jeele ${ }^{1 *}$, Rukia Omar Barei Addow² and Mohamed Farah Yusuf Mohamud ${ }^{1}$
}

\begin{abstract}
Nephrotic syndrome (NS) was first described in 1827 as the presence of proteinuria of $\geq 3.5 \mathrm{~g} / 24 \mathrm{~h}$, hypoalbuminemia $<3.0 \mathrm{~g} / \mathrm{dl}$, peripheral edema, hyperlipidemia, lipiduria, and increased thrombotic risk. Nephrotic syndrome has an incidence of three cases per 100,000 each year in adults. Nephrotic syndrome also has serious complications due to hypercoagulable state in both various venous and arteries which could lead thromboembolic events. The pathophysiology of hypercoagulability in the nephrotic syndrome is due to an imbalance of prothrombotic and antithrombotic factors, as well as impaired thrombolytic activities. Here, we will present a 19-year-old woman who presented to the emergency department complaining of chest pain and shortness of breath for 3 days. The patient was quickly diagnosed with pulmonary embolism and inferior vena cava thrombosis as a complication of nephrotic syndrome, allowing prompt initiation of anticoagulant therapy. After 2 weeks of admission, the patient's condition resolved, her laboratory results returned to almost normal and the patient was discharged with oral prednisolone, coumadin, atorvastatin, and ramipril. We aim to determine which is the likely cause of pulmonary embolism in patients with nephrotic syndrome.
\end{abstract}

Keywords: Nephrotic syndrome, Thromboembolism, Inferior vena cava thrombosis, Pulmonary embolism

\section{Introduction}

Nephrotic syndrome (NS) was first described in 1827 as the presence of proteinuria of $\geq 3.5 \mathrm{~g} / 24 \mathrm{~h}$, hypoalbuminemia $<3.0 \mathrm{~g} / \mathrm{dl}$, peripheral edema, hyperlipidemia, lipiduria, and increased thrombotic risk [1,2]. Nephrotic syndrome has an incidence of three cases per 100,000 each year in adults [3]. Thromboembolism, including pulmonary embolism, deep venous thrombosis (DVT), renal vein thrombosis, and inferior vena cava thrombosis has been reported as a life-threatening complication of nephrotic syndrome patients [4]. Enhanced platelet

\footnotetext{
* Correspondence: drjeele@gmail.com

${ }^{1}$ Mogadishu Somali Turkish Training and Research Hospital, Mogadishu, Somalia

Full list of author information is available at the end of the article
}

aggregation and loss of anticoagulant proteins including antithrombin III through renal are thought to cause the excessive thrombotic risk in patients with nephrotic syndrome $[4,5]$. Here, we present a case of an unusual combination of multiple venous thromboses as the presentation of nephrotic syndrome.

\section{Case report}

A 19-year-old woman, previously healthy, nonsmoker, non-diabetic came to the emergency department with a complaint of chest pain and shortness of breath for 3 days.

She never had a similar incident before. She does not have any history of drug use including oral contraceptive drugs. On examination, the patient looked ill, anxious, 
tachyapneic, and edematous. On vital signs, her respiratory rate was 23 breath/min, blood pressure $110 / 70 \mathrm{~mm} /$ $\mathrm{Hg}$, pulse $112 \mathrm{bpm}$, and oxygen saturation was $90 \%$. Head and neck examination were unremarkable. Tachycardia was the only prominent sign of cardiovascular findings. The respiratory evaluation revealed diminished breath sounds in both lungs. Grade 2+ lower limb edema noted during the examination while other systems examination were unremarkable. Laboratory investigations including complete blood count and serum electrolytes revealed normal range. Regarding the liver function test, AST was $35 \mathrm{U} / \mathrm{L}, \mathrm{ALT}$ was $16 \mathrm{U} / \mathrm{L}$, total protein was $4 \mathrm{~g} / \mathrm{dl}$, and $\mathrm{Al}$ bumin was $1.9 \mathrm{~g} / \mathrm{dl}$. Total cholesterol was $450 \mathrm{mg} / \mathrm{dl}$ and lactate dehydrogenase was $639 \mathrm{U} / \mathrm{l}$. HBV, HCV, HIV, and $\mathrm{RF}$ were all in the normal range or negative. The $\mathrm{D}$-dimer $(>4 \mu \mathrm{g} / \mathrm{ml})$ and $24-\mathrm{h}$ urinary protein excretion $(10 \mathrm{~g})$ were positive. As there had no obvious predisposing factor for PE, tests for the etiology of the thrombophilic state

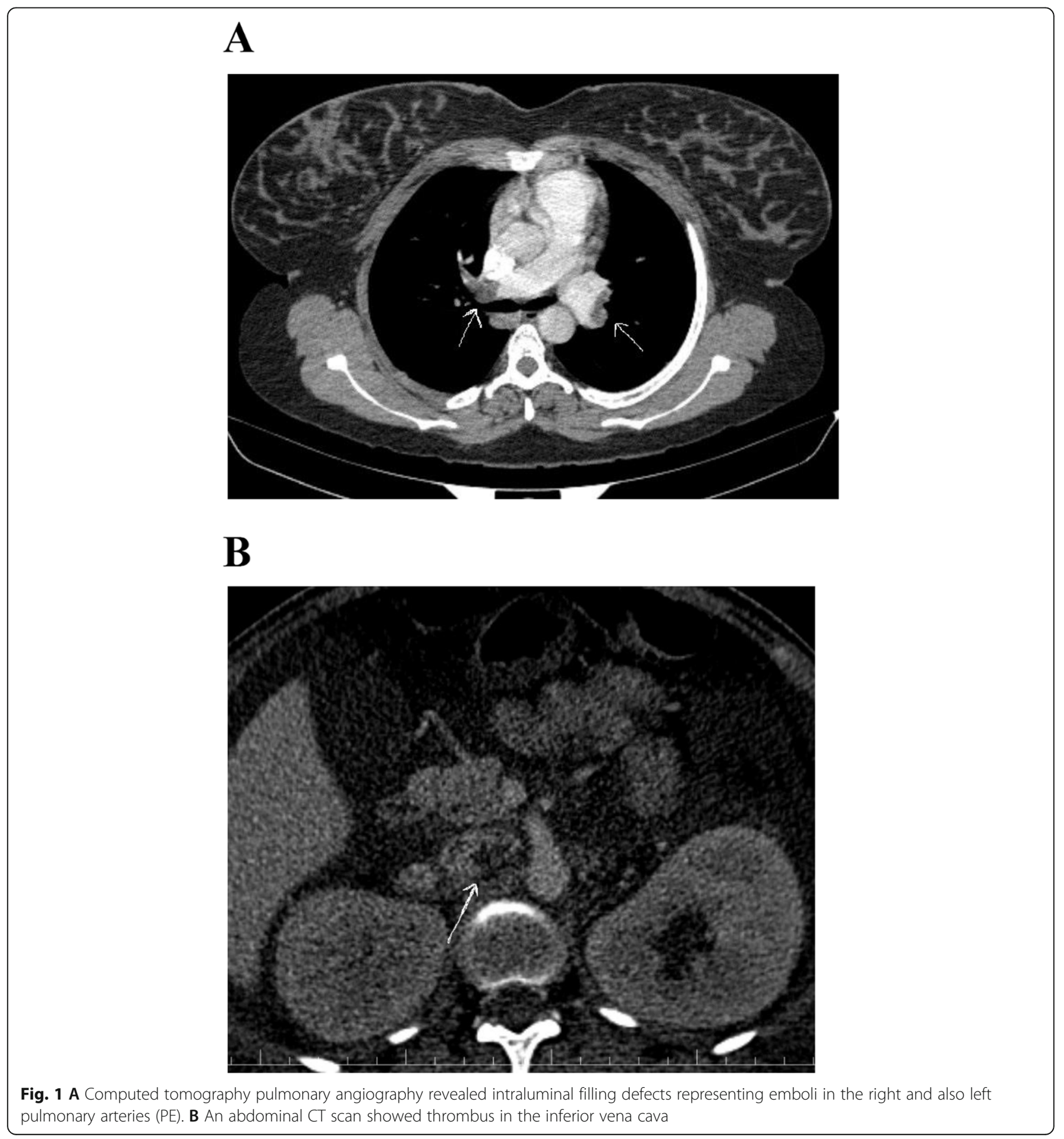


were ordered. While waiting the results in the emergency, oxygen therapy with high flow nasal cannula was started along with subcutaneous low molecular weight heparin.

Chest X-ray and electrocardiograms were unremarkable. Abdominal ultrasonography detected mild ascites. Computed tomography (CT) angiography of the chest and abdomen revealed thrombus at both right and left pulmonary arteries and inferior vena cava (Fig. 1A and B). The patient was admitted for nephrotic syndrome complicated with pulmonary embolism and inferior vena cava thrombosis.

The patient was started on heparin, ramipril, methylprednisolone, and atorvastatin. Two days later, coumadin tablet was added. After 2 weeks of hospitalization, the patient symptoms resolved, lower limb edema decreased, proteinuria was not detected, and albumin returned to the normal range. The patient was discharged with oral prednisolone, coumadin, atorvastatin, and ramipril. Close follow-up was recommended for the patient. The patient's 6-month follow-up revealed no complaints and no thrombus on the repeated chest CT angiography (Fig. 2).

\section{Discussion}

Patients with nephrotic syndrome carry a high risk of both venous and arterial thrombosis [4]. Pulmonary embolism, deep venous thrombosis (DVT), renal vein thrombosis, and inferior vena cava thrombosis are reported as life-threatening complications of nephrotic syndrome $[4,5]$.

The etiology of NS is divided into primary, which includes focal segmental glomerulosclerosis (FSGS), membranous nephropathy $(\mathrm{MN})$, and minimal change disease
(MCD), and secondary to systemic diseases which included diabetes mellitus, systemic lupus erythematosus, multiple myeloma, amyloidosis, and infections [6]. The pathophysiology of hypercoagulability in the nephrotic syndrome is due to imbalances of prothrombotic and antithrombotic factors, impaired thrombolytic activity, and other important contributing factors such as intravascular volume depletion, the use of diuretics, immobilization, and procoagulant diatheses (such as protein $\mathrm{C}$ and protein $\mathrm{S}$ deficiencies) [7].

Hull RP et al. reported deep venous thrombosis (DVT) at the lower limbs as the most common complication of nephrotic syndrome, but also noted thrombosis at renal and pulmonary vessels [6]. Our case initially presented with pulmonary embolism as a complication of NS with no previous history of NS which is uncommon.

Similar to the presented case, Peces $\mathrm{R}$ et al. [8] reported a 42-year-old male that presented with multiple venous thromboses and pulmonary artery embolism as a complication of nephrotic syndrome. In our case, pulmonary embolism and inferior vena cava thrombosis were complications of nephrotic syndrome while persistent adequate renal blood flow prevented renal infarction.

\section{Conclusion}

Nephrotic syndrome is a risk factor for venous thromboembolism due to increased renal loss of anticoagulant proteins included antithrombin III and increased production of pro-thrombotic factors by the liver. The possible occurrence of PE in a young person with nephrotic syndrome should not be missed. Early diagnosis and management of nephrotic syndrome may prevent the occurrence of venous thromboembolism (VTE).

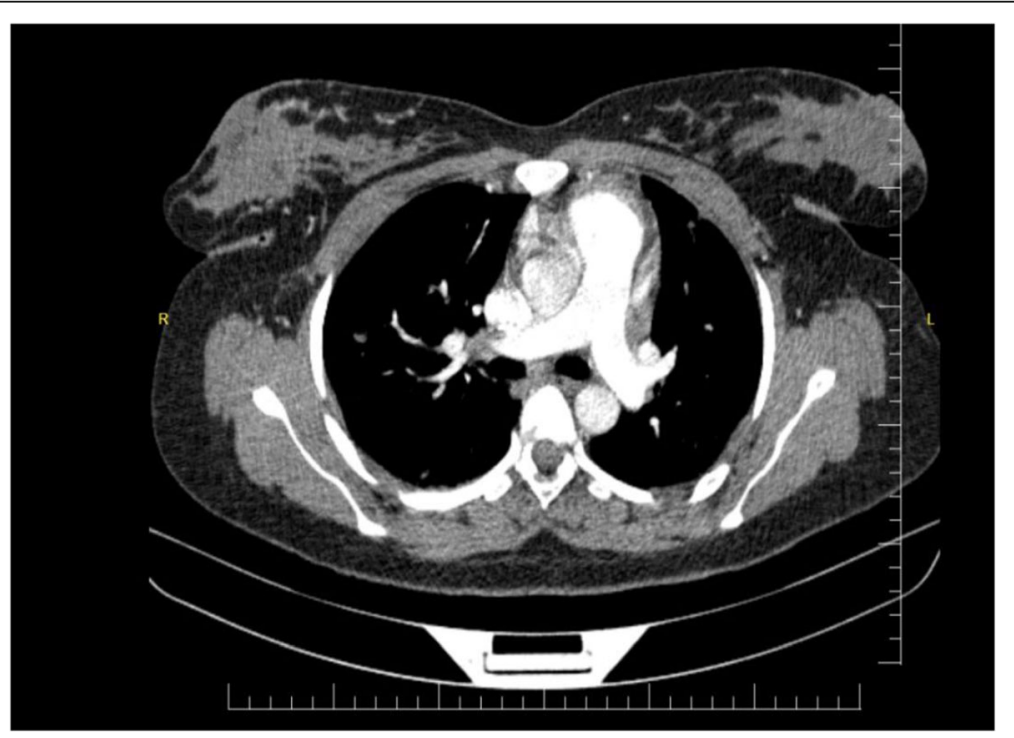

Fig. 2 Computed tomography pulmonary angiography revealed normal pulmonary vessels with no thrombus or emboli 


\section{Abbreviations}

CT: Computed tomography; DVT: Deep venous thrombosis; FSGS: Focal segmental glomerulosclerosis; HBV: Hepatitis B virus; $\mathrm{HCV}$ : Hepatitis C virus; HIV: Human immunodeficiency virus; MCD: Minimal change disease;

MN: Membranous nephropathy; NS: Nephrotic syndrome; RF: Rheumatoid factor; VTE: Venous thromboembolism

\section{Acknowledgements}

We thank the patient who gave her consent to be involved in this case study.

\section{Authors' contributions}

Mohamed OOJ brought the idea of the case study, performed data collection, and prepared the manuscript. Rukia OBA participated in the manuscript preparation. Mohamed FYM participated in the manuscript preparation. All authors read and approved the manuscript before submitting.

\section{Funding}

The authors declare that they have no funding source.

\section{Availability of data and materials}

The data is available from the corresponding author and can be accessed if requested.

\section{Declarations}

\section{Ethics approval and consent to participate}

This case study was reviewed and approved by Mogadishu Somali Turkish Training and Research Hospital ethic committee. Written consent had obtained from the patient.

\section{Consent for publication}

All authors gave their consent for this case study to be published.

\section{Competing interests}

The authors declare that they have no competing interests.

\section{Author details}

'Mogadishu Somali Turkish Training and Research Hospital, Mogadishu,

Somalia. ${ }^{2}$ Jazeera University Hospital, Mogadishu, Somalia.

Received: 12 August 2020 Accepted: 27 July 2021

Published online: 23 August 2021

\section{References}

1. Bennett WM. Renal vein thrombosis in nephrotic syndrome. Ann Intern Med. 1975:83(4):577-8. https://doi.org/10.7326/0003-4819-83-4-577.

2. Cameron JS, Hicks J. The origins and development of the concept of a nephrotic syndrome'. Am J Nephrol. 2002;22(2/3):240-7. https://doi.org/1 $0.1159 / 000063768$

3. Llach F. Thromboembolic complications in nephrotic syndrome: coagulation abnormalities, renal vein thrombosis, and other conditions. Postgraduate Med. 1984;76(6):111-23. https://doi.org/10.1080/00325481.1 984.11698782.

4. Kerlin BA, Ayoob R, Smoyer WE. Epidemiology and pathophysiology of nephrotic syndrome-associated thromboembolic disease. Clin J Am Soc Nephrol. 2012;7(3):513-20. https://doi.org/10.2215/CJN.10131011.

5. Llach F. Hypercoagulability, renal vein thrombosis, and other thrombotic complications of nephrotic syndrome. Kidney Int. 1985;28(3):429-39. https:// doi.org/10.1038/ki.1985.149

6. Hull RP, Goldsmith DJ. Nephrotic syndrome in adults. Bmj. 2008;336(7654): 1185-9. https://doi.org/10.1136/bmj.39576.709711.80

7. Singhal R, Brimble KS. Thromboembolic complications in the nephrotic syndrome: pathophysiology and clinical management. Thrombosis Res. 2006;118(3):397-407. https://doi.org/10.1016/j.thromres.2005.03.030.

8. Peces R, Pobes A, Rodriguez M, Navascués RA, Ortega F, Alvarez-Grande J. Multiple venous thrombosis and massive pulmonary artery thrombus as the presenting features of steroid-responsive nephrotic syndrome. Nephrol Dialysis Transplantation. 1999;14(5):1306-9. https://doi.org/10.1093/ndt/14. 5.1306.

\section{Publisher's Note}

Springer Nature remains neutral with regard to jurisdictional claims in published maps and institutional affiliations.

\section{Ready to submit your research? Choose BMC and benefit from:}

- fast, convenient online submission

- thorough peer review by experienced researchers in your field

- rapid publication on acceptance

- support for research data, including large and complex data types

- gold Open Access which fosters wider collaboration and increased citations

- maximum visibility for your research: over $100 \mathrm{M}$ website views per year

At $\mathrm{BMC}$, research is always in progress.

Learn more biomedcentral.com/submissions 